\title{
ROLA MINISTRA FINANSÓW W ZACIĄGANIU ZOBOWIĄZAŃ FINANSOWYCH W IMIENIU SKARBU PAŃSTWA. CZĘŚĆ I
}

\section{UWAGI WPROWADZAJĄCE}

Problematyka długu publicznego i zarządzania nim wpisuje się we współczesne ujęcie normatywne finansów publicznych ${ }^{1}$. Zagadnienie to powszechnie kojarzone jest ze stanem finansów publicznych, a w związku z tym poddawane badaniom naukowym pod różnorodnym kątem, w tym jego ram instytucjonalnych. Prowadzone badania naukowe wskazują, że w obszarze tym Minister Finansów zajmuje pozycję szczególną ${ }^{2}$. Wydaje się, że oprócz dotychczas podnoszonych problemów, godne uwagi jest także zagadnienie zaciągania zobowiązań w imieniu Skarbu Państwa, w szczególności, gdy w ustawie zasadniczej poświęcono tej materii odrębne miejsce ${ }^{3}$. Bezpośrednią realizację konstytucyjnych wymogów przewidują: ustawa o finansach publicznych oraz ustawa o poręczeniach i gwarancjach ${ }^{4}$, które powierzają kompetencje do zaciągania zobowiązań finansowych w imieniu

Dr hab. Beata Kucia-Guściora, prof. KUL - Katedra Finansów i Prawa Finansowego, Instytut Nauk Prawnych, Wydział Prawa, Prawa Kanonicznego i Administracji, Katolicki Uniwersytet Lubelski Jana Pawła II, Al. Racławickie 14, 20-950 Lublin; e-mail: beakuc@kul.pl; https://orcid. org/0000-0002-6671-0334

${ }^{1}$ Art. 3 ustawy z dnia 27 sierpnia 2009 r. o finansach publicznych, Dz. U. z 2019 r., poz. 869 z późn. zm. [dalej cyt.: u.f.p.]

${ }^{2}$ Zob. P. PANFIL, Prawne i finansowe uwarunkowania dlugu skarbu państwa, Warszawa: Wolters Kluwer, 2011, passim; K. Niziol, Państwowy dlug publiczny - aspekty normatywne, Szczecin: Polgres Multimedia 2013, passim; B. KuCiA-Guściora, Rola ministra właściwego do spraw finansów publicznych w kształtowaniu zakresu państwowego dlugu publicznego. Wybrane problemy, „Roczniki Nauk Prawnych” 27 (2017), s. 41-62; TAŻ: Kontrola i programowanie państwowego dlugu publicznego z perspektywy kompetencji ministra właściwego do spraw finansów publicznych, „Krytyka Prawa. Niezależne Studia nad Prawem" 1 (2017), nr 1, s. 63-86.

${ }^{3}$ Art. 216 ust. 2 oraz ust 4 Konstytucji Rzeczypospolitej Polskiej z dnia 2 kwietnia 1997 r., Dz. U. Nr 78, poz. 483 z póżn. zm. [dalej cyt.: Konstytucja RP].

${ }^{4}$ Ustawa z dnia 8 maja 1997 r. o poręczeniach i gwarancjach udzielanych przez Skarb Państwa oraz niektóre osoby prawne, Dz. U. z 2020 r., poz. 122 [dalej cyt.: ustawa o poręczeniach i gwarancjach]. 
Skarbu Państwa Ministrowi Finansów. Przedmiotowe zagadnienie obejmuje trzy płaszczyzny badawcze: emisję skarbowych papierów wartościowych, zaciąganie przez Skarb Państwa pożyczek i kredytów oraz udzielanie poręczeń i gwarancji ${ }^{5}$.

Celem badawczym niniejszej pracy jest przeanalizowanie roli Ministra Finansów w tym obszarze, w celu udzielenia odpowiedzi na pytanie nie tylko o ramy prawne kompetencji Ministra, ale również o poziom dyskrecjalności jego działań, a także ustalenie położenia prawnego Ministra Finansów w kontekście jego relacji z innymi podmiotami, czyli ustalenie czy kompetencje zastrzeżone dla Ministra Finansów są wyrazem jego swoistej preponderencji czy raczej świadczą o jego służebnej, instrumentalnej roli. Proponowane ujęcie zadania badawczego w szerszej perspektywie może być przyczynkiem do refleksji naukowej nad funkcjonowaniem organów reprezentujących Skarb Państwa z dwóch perspektyw - dominium oraz imperium.

\section{ROLA MINISTRA FINANSÓW \\ W PROCESIE EMISJI PAPIERÓW WARTOŚCIOWYCH}

Realizacja konstytucyjnego nakazu określania z trybu i zasad emisji skarbowych papierów wartościowych ${ }^{6}$ nastąpiła w ustawie o finansach publicznych (art. 216 ust. 2 Konstytucji RP). Z tej regulacji prawnej wynikają szczególne kompetencje Ministra Finansów. Po pierwsze, należy podkreślić, że Minister Finansów odgrywa istotną rolę jako organ uprawniony do emisji lub wystawiania skarbowych papierów wartościowych (art. 95 ust. 1, 2, i 5 u.f.p.). Po drugie, Minister Finansów upoważniony został do wydania rozporządzeń określających warunki emisji danego rodzaju papierów wartościowych (art. 97 u.f.p.). Po trzecie, Ministrowi Finansów powierzony został obowiązek wydania listu emisyjnego, określającego szczegółowe warunki emisji skarbowych papierów wartościowych.

${ }^{5} \mathrm{~W}$ części pierwszej pracy zostanie omówiona pierwsza z wymienionych płaszczyzn, natomiast dwie kolejne w „Rocznikach Nauk Prawnych” 30 (2020), nr 1.

${ }^{6}$ Pojęcie skarbowych papierów wartościowych zostało sformułowane w art. 95 u.f.p. Należy je uznać jako jedną z kategorii papierów wartościowych, w związku ze stanowiskiem prezentowanym w doktrynie, że w polskim prawie obowiązuje zasada numerus clausus papierów wartościowych oznaczającej że papierem wartościowym może być tylko taki dokument, któremu przepis szczególny nadaje taki charakter. W związku z tym regulacje u.f.p. mają charakter lex specialis wobec ogólnych przepisów kodeksu cywilnego (Księga trzecia tytuł XXXVII, dział II ustawy z dnia 23 kwietnia 1964 r. Kodeks cywilny, Dz. U. z 2019 r., poz. 1145 z późn. zm. [dalej cyt.: k.c.]). Na temat skarbowych papierów wartościowych zob. m.in. J. FRĄTCZAK, Istota skarbowych papierów wartościowych, „Przegląd Prawa Handlowego” 8 (2005), s. 43 n. 
Uprawnienia Ministra Finansów można pogrupować z uwagi na charakter świadczenia, do jakiego wykonania zobowiązany jest Skarb Państwa. Po pierwsze, ustawa o finansach publicznych wskazuje, iż Minister Finansów ma wyłączne prawo do emitowania lub wystawiania skarbowych papierów wartościowych opiewających na świadczenia pieniężne. Po drugie, Minister Finansów emituje skarbowe papiery wartościowe opiewające na świadczenia pieniężnie uprawniające do określonych świadczeń niepieniężnych w zamian za te skarbowe papiery wartościowe. Po trzecie, uprawnienie Ministra obejmuje emisję skarbowych papierów wartościowych opiewających na świadczenia niepieniężne. Uwagę zwraca redakcja powyższej przytoczonych przepisów. Tylko w odniesieniu do emisji skarbowych papierów wartościowych opiewających na świadczenia pieniężne ustawodawca użył sformułowania ,wyłączne prawo”, w pozostałych przypadkach, pomimo, że Minister Finansów jest jedynym wskazanym organem kompetentnym nie użyto tego sformułowania. Można się zastanawiać nad uzasadnieniem tej redakcji przepisów, które jawią się jako pewna niekonsekwencja - skoro w pozostałych przypadkach także wymieniony został jako organ właściwy „wyłącznie Minister Finansów”. Samo rozróżnienie kategorii papierów wartościowych wypływa z ich charakteru. Ale redakcja powyższych przepisów jest raczej prozaiczna, bowiem uzasadniona jest zmianą w strukturze administracji rządowej związanej z likwidacją urzędu Ministra Skarbu Państwa. W pierwotnej wersji ustawy o finansach publicznych emisja skarbowych papierów wartościowych opiewających na świadczenia pieniężne była traktowana jako formą pożyczki publicznej, w związku z tym kompetencje do ich emisji powierzone zostały Ministrowi Finansów, natomiast emisja papierów wartościowych na opiewających na świadczenia niepieniężne traktowane były jako forma gospodarowania mieniem państwowym należały do kompetencji Ministra Skarbu Państwa działającego w porozumieniu z Ministrem Finansów. Po zmianach pozostawiono te kompetencje w gestii Ministra Finansów, jako niewymagające ani konsultacji ani zgody innego organu. Nastąpiło więc rozszerzenie uprawnień Ministra Finansów w tym obszarze wskazujące na pełną autonomię tego organu w ich realizacji. Kluczowa rola Ministra Finansów jest o tyle znamienna, że emisja papierów wartościowych jest instrumentem do realizacji zasadniczego celu, jakim jest sfinansowanie pożyczkowych potrzeb budżetu państwa oraz zarządzania długiem Skarbu Państwa, które to działania leżą w kompetencji tego organu. Należy zatem uznać, że działania Ministra Finansów w tym przypadku urzeczywistniają aktywność finansową Skarbu Państwa, z tym, że Minister nie posługuje się metodami władczymi, a mającymi znamiona cywilnoprawne ${ }^{7}$. Szczególny status emi-

${ }^{7}$ Tak: K. JALOSZYŃSKA, Z problematyki prawnej skarbowych papierów wartościowych, [w:] Prawo finansowe i nauka prawa finansowego na przełomie wieków, red. A. Kostecki, Kraków: Wydawnictwo Zakamycze 2000, s. 216. 
tenta reprezentowanego przez Ministra Finansów daje pełną gwarancję realizacji uprawnień nabywców. Potwierdza to zasada nieograniczonej odpowiedzialności Skarbu Państwa za zobowiązania wynikające $\mathrm{z}$ wyemitowanych lub wystawionych skarbowych papierów wartościowych (art. 95 ust. 6 u.f.p.).

Warto podkreślić, że Minister Finansów reprezentując Skarb Państwa jest zwolniony z obowiązku uzyskania opinii prawnej Prokuratorii Generalnej w odniesieniu do zaciągania pożyczek i kredytów, emisji skarbowych papierów wartościowych oraz innych operacji związanych bezpośrednio z zarządzaniem państwowym długiem Skarbu Państwa nawet wtedy, gdy wartość przedmiotu czynności prawnej przekracza kwotę 100000000 zł (art. 3a u.f.p.). Ocena dogmatyczna wyłączenia działania Prokuratorii Generalnej pozwala na konstatację o wyraźnym wzmocnieniu autonomii Ministra Finansów, z praktycznego zaś punktu widzenia ma na celu zagwarantowanie procedury bardzo sprawnego i niezakłóconego trybu realizacji pożyczkowych potrzeb budżetu państwa ${ }^{8}$.

Kompetencje Ministra Finansów dotyczące emisji skarbowych papierów wartościowych doznają jednak ograniczenia ustawowego, jeśli chodzi o limit wysokości ich emisji. Limit ten corocznie ustalany jest w ustawie budżetowej. Rozwiązanie to uzasadnione jest koniecznością zabezpieczenia przed wzrostem długu publicznego. Zaznaczyć należy, że w praktyce ustawa budżetowa ustala odrębnie granice przyrostu zadłużenia na koniec roku budżetowego, jak również granice kwotowe wartości nominalnej nowo wyemitowanych skarbowych papierów wartościowych na przeznaczonych na przedterminową spłatę, wykup lub zamianę innych niż skarbowe papiery wartościowe zobowiązań Skarbu Państwa, a także na spłatę zobowiązań Skarbu Państwa wynikających z ustaw, orzeczeń sądów lub innych tytułów ${ }^{9}$. W ocenie tego rozwiązania należy podkreślić z jednej strony szczególny udział Ministra Finansów w procedurze przygotowania projektu ustawy budżetowej, a także jego doniosłą rolę w opracowaniu Strategii zarządzania dtugiem, co $\mathrm{w}$ praktyce na etapie przedlegislacyjnym przesądza o realnym wpływie tego Ministra na kształt regulacji ustawowej. Z drugiej strony, dużo ważniejsza wydaje się jednak wymowa prawnoustrojowa. Uwidacznia się tu bowiem rola władzy ustawodawczej decydującej ostatecznie o granicach emisji skarbowych papierów wartościowych oraz zaciągniętych kredytach i pożyczkach. Co znamienne, limity określane corocznie w ustawach budżetowych nie są bezpośrednio adresowane do Ministra Finansów, ich ewentualne niezachowanie w praktyce będzie więc obcią-

${ }^{8}$ Zob. Z. OfiARSKI, Komentarz do art. 3, [w:] Ustawa o finansach publicznych. Komentarz, red. Z. Ofiarski, Warszawa: Wolters Kluwer 2019, s. 88.

${ }^{9}$ Zob. m.in. art. 5 ustawy budżetowej na 2019 rok, Dz. U. z 2019 r., poz. 198; art. 5 ustawy budżetowej na rok 2020 z dnia 14 lutego 2020 r., Dz. U. poz. 571. 
żało wykonawcę ustawy budżetowej, czyli Radę Ministrów, która ostatecznie in pleno ponosi odpowiedzialność za realizacje ustawy budżetowej przed Sejmem. Niemniej to właśnie działania Ministra Finansów, o których będzie mowa poniżej, zarówno w obszarze stanowienia prawa (rozporządzenia emisyjne), jak i czynności faktycznych (list emisyjny) mają decydujące przełożenie na wypełnienie norm wynikających z ustawy budżetowej.

Z perspektywy oceny roli Ministra Finansów, jak i przedmiotowo samego procesu emisji skarbowych papierów wartościowych ważną kompetencją jest realizacja ustawowej delegacji do wydania rozporządzenia określającego warunki emitowania danego rodzaju skarbowych papierów wartościowych (art. 97 u.f.p.). Minister Finansów został wyposażony w uprawnienia prawotwórcze do określenia ram prawnych sposobu przeprowadzania emisji papierów wartościowych. Regulacje te stanowią więc dookreślenie kształtu normatywnego papieru wartościowego określonego ustawą.

Wskazane delegacje do wydania rozporządzeń zawierają wytyczne co do treści oraz założeń, jakimi Minister Finansów obowiązany jest kierować się realizując ustawowe upoważnienie. Znamienne jest, że delegacja ustawowa, co prawda wskazuje szczegółowe warunki emisji skarbowych papierów wartościowych, ale nie jest wyczerpująca, skoro zostało użyte sformułowanie „w szczególności”. Zatem Ministrowi Finansów realizującemu ustawową delegację pozostawiono możliwość określenia innych niewymienionych warunków emisji. W związku z tym w literaturze przedmiotu już od dawna stawiany był zarzut naruszenia standardów konstytucyjnych, co do określania w akcie o randze ustawy zasad i trybu emisji papierów wartościowych ${ }^{10}$. Sumując można więc stwierdzić, że omówiona konstrukcja daje Ministrowi w omawianym zakresie pewne pole do działań dyskrecjonalnych. Minister Finansów w drodze rozporządzenia określa kryteria podmiotowe oraz przedmiotowe ${ }^{11}$ emisji skarbowych papierów wartościowych.

${ }^{10}$ Tak. Z. OfIARSKI, Aspekty prawne reglamentacji emisji skarbowych papierów wartościowych o charakterze dlużnym, [w:] Deficyt budżetowy i dtug publiczny w wybranych krajach europejskich, red. E. Ruśkowski, Białystok: Wydawnictwo Wyższej Szkoły Finansów i Zarządzania w Białymstoku 2003, s. 232; por. P. ZAWADZKA, Komentarz do art. 97, [w:] Ustawa o finansach publicznych. Komentarz, s. 636.

${ }^{11}$ Zgodnie z art. 97 u.f.p. w omawianym rozporządzeniu Minister Finansów określa podmioty, którym skarbowe papiery wartościowe danej emisji są oferowane do nabycia na rynku pierwotnym, a także jednostkową wartość nominalną, walutę, w której może następować emisja, lub sposób określenia waluty emisji, zasady i tryb sprzedaży, w tym termin lub sposób ustalenia ceny sprzedaży emitowanych papierów wartościowych na rynku pierwotnym, ograniczenia co do obrotu skarbowymi papierami wartościowymi na rynku pierwotnym i wtórnym, sposób realizacji świadczeń z tytułu skarbowych papierów wartościowych. Por: A. Miкos-SiтeK, P. ZAPADKA, Komentarz do art. 97, [w:] Ustawa o finansach publicznych. Komentarz, red. W. Misiąg, Warszawa: C.H. Beck 2019, s. 397. 
Warto zwrócić uwagę na sposób określenia kryteriów, jakie Minister Finansów obowiązany jest uwzględnić wydając omawiane akty wykonawcze. W odniesieniu do kategorii rozporządzeń odnoszących się do skarbowych papierów wartościowych inkorporujących prawa do świadczeń pieniężnych Minister kieruje się koniecznością optymalnego zaspokajania potrzeb pożyczkowych budżetu państwa oraz efektywnego zarządzania długiem Skarbu Państwa. W odniesieniu do rozporządzenia określającego warunki emitowania skarbowych papierów wartościowych opiewających na świadczenia pieniężne uprawniające do określonych świadczeń niepieniężnych przesłanką, jaką obowiązany jest uwzględnić, jest konieczność zapewnienia efektywnego zarządzania długiem oraz aktywami Skarbu Państwa. Na tym tle można poczynić kilka uwag. Po pierwsze, wytyczne te są związane z kompetencją ogólną Ministra Finansów dotyczącą finansowania pożyczkowych potrzeb budżetu państwa oraz zarządzania długiem Skarbu Państwa. Po drugie, wskazanie przesłanek nastąpiło przy zastosowaniu koniunkcji, zatem wydaniu rozporządzenia musi towarzyszyć uwzględnienie tych przesłanek łącznie. Po trzecie, kryteria jakimi obowiązany jest kierować zostały sformułowane poprzez użycie zwrotów niedookreślonych „optymalne zaspokajanie” oraz „efektywne zarządzanie”. Po czwarte, użycie formuły „kierując się koniecznością” odnoszącej się do sposobu działania Ministra, sugeruje związanie Ministra wskazanymi kryteriami. Sumując należy podkreślić z jednej strony bardzo szerokie kompetencje Ministra, co do reglamentacji zasad emisji, jak i wprowadzania do obrotu skarbowych papierów wartościowych, a z drugiej strony trudny do zmierzenia stopień ich realizacji skoro miara ta opiera się o niedookreślone, ocenne przesłanki, jakimi ma się on kierować. Należy więc uznać, że to rozwiązanie ustawowe w sposób oczywisty wskazuje na szczególną rolę Ministra Finansów, ale jednocześnie konstrukcja ta pozostawia mu pole do działań dyskrecjonalnych.

Wykonując upoważnienie ustawowe Minister Finansów wydał kilka rozporządzeń wykonawczych odróżnialnych przede wszystkim z uwagi na kategorie skarbowych papierów wartościowych oraz poziom sprzedaży, a także podmioty, którym są te papiery oferowane ${ }^{12}$.

\footnotetext{
${ }^{12}$ Aktualnie obowiązuje sześć aktów wykonawczych: rozporządzenie Ministra Finansów z dnia 30 sierpnia 2013 r. w sprawie warunków emitowania obligacji skarbowych oferowanych w sprzedaży hurtowej, Dz. U poz. 1089 z późn. zm. [dalej cyt.: rozporządzenie MF w sprawie warunków emitowania obligacji skarbowych oferowanych w sprzedaży hurtowej]; rozporządzenie Ministra Finansów z dnia 30 sierpnia 2013 r. w sprawie warunków emitowania bonów skarbowych, Dz. U. poz. 1088 z późn. zm. [dalej cyt.: rozporządzenie MF w sprawie warunków emitowania bonów skarbowych]; rozporządzenie Ministra Finansów z dnia 28 grudnia 2010 r. w sprawie warunków emitowania obligacji skarbowych uprawniających do określonych świadczeń niepieniężnych, Dz. U. Nr 258, poz. 1756 [dalej cyt.: rozporządzenie MF w sprawie warunków emitowania obligacji skarbowych uprawniających do określonych świadczeń niepieniężnych]; rozporządzenie Ministra Finansów
} 
Kompleksowa i wszechstronna analiza treści aktualnie obowiązujących rozporządzeń z uwagi na charakter niniejszego opracowania nie jest konieczna, można natomiast wskazać kilka określonych w nich uprawnień Ministra Finansów wskazujących na jego kluczową rolę w procesie emisji skarbowych papierów wartościowych.

Zagadnieniem jakie warto poruszyć jest rola Ministra Finansów w organizacji rynku skarbowych papierów wartościowych. W związku z tym, że Minister Finansów nie posiada zaplecza organizacyjno-technicznego niezbędnego do emisji papierów wartościowych na rynku pierwotnym, taką rolę na podstawie umowy zawartej z Ministrem Finansów pełni agent emisji. W zależności od kategorii skarbowych papierów wartościowych agentem emisji jest podmiot odpowiedzialny za organizację przetargów oraz obsługę obligacji czy bonów skarbowych ${ }^{13}$. W przypadku obligacji oferowanych w sprzedaży detalicznej, czy obligacji uprawniających od określonych świadczeń niepieniężnych, agentami emisji są podmioty oferujące sprzedaż na rynku pierwotnym i obsługę tych obligacji ${ }^{14}$. Ponadto w odniesieniu do tego rodzaju obligacji na podstawie umowy Minister Finansów może przyznać wyłączne prawo składania ofert zakupu na obligacje w całości lub części emisji1'. W odniesieniu do obligacji skarbowych oferowanych na rynkach zagranicznych Minister Finansów może na podstawie umowy powierzyć oferowanie obligacji na rynku pierwotnym bankom, instytucjom kredytowym, instytucjom finansowym

z dnia 15 grudnia $2010 \mathrm{r}$. w sprawie warunków emitowania obligacji skarbowych oferowanych na rynkach zagranicznych, Dz. U. z 2016 r., poz. 1884 [dalej cyt.: rozporządzenie MF w sprawie warunków emitowania obligacji skarbowych oferowanych na rynkach zagranicznych]; rozporządzenie Ministra Finansów z dnia 3 grudnia 2010 r. w sprawie warunków emitowania obligacji skarbowych przeznaczonych na zamianę zobowiązań Skarbu Państwa, Dz. U. Nr 237, poz. 1574 [dalej cyt.: rozporządzenie MF w sprawie warunków emitowania obligacji skarbowych przeznaczonych na zamianę zobowiązań Skarbu Państwa]; rozporządzenie Ministra Finansów z dnia 3 grudnia 2010 r. w sprawie warunków emitowania obligacji skarbowych oferowanych w sieci sprzedaży detalicznej, Dz. U. z 2019 r. poz. 944 [dalej cyt.: rozporządzenie MF w sprawie warunków emitowania obligacji skarbowych oferowanych w sieci sprzedaży detalicznej]. Dodać należy, że także pod rządami poprzednio obowiązujących ustaw o finansach publicznych w analogiczny sposób - wydając kilka rozporządzeń zwanych emisyjnymi Minister Finansów realizował delegację ustawową.

$13 \S 10$ rozporządzenia MF w sprawie warunków emitowania obligacji skarbowych oferowanych w sprzedaży hurtowej oraz $\S 10$ rozporządzenia MF w sprawie warunków emitowania bonów skarbowych.

${ }^{14} \S 3$ pkt 8 rozporządzenia MF w sprawie warunków emitowania obligacji skarbowych oferowanych w sieci sprzedaży detalicznej; § 2 pkt 4 rozporządzenia MF w sprawie warunków emitowania obligacji skarbowych uprawniających do określonych świadczeń niepieniężnych.

${ }^{15} \S 7$ rozporządzenia MF w sprawie warunków emitowania obligacji skarbowych oferowanych w sieci sprzedaży detalicznej. 
ich oddziałom lub konsorcjum tych podmiotów ${ }^{16}$. Na podstawie umów zawartych z Ministrem Finansów, za sprzedaż skarbowych papierów wartościowych dla inwestorów instytucjonalnych (dotyczy to obligacji skarbowych i bonów skarbowych) oferowanych w przetargach odpowiedzialny jest Narodowy Bank Polski ${ }^{17}$.

Minister Finansów zawiera także umowy z Dealerami Skarbowych Papierów Wartościowych, na podstawie których uzyskują oni prawo do składania ofert na przetargach obligacji ${ }^{18}$. Podmioty te są wyłaniane na podstawie konkursu polegającego na ocenie okresowej uwzględniającej średnią punktów przyznawanych w kryteriach określonych w regulaminie pełnienia funkcji Dealera Skarbowych Papierów Wartościowych ${ }^{19}$, zaś umowa o pełnienie funkcji Dealera Skarbowych Papierów Wartościowych zawierana jest przez Ministra Finansów na czas nieokreślony, z 14 dniowym terminem wypowiedzenia. W odniesieniu do banków państwowych nieposiadających statusu Dealera Skarbowych Papierów Wartościowych Minister Finansów w odrębnej umowie określa szczegółowe warunki uczestnictwa w przetargach ${ }^{20}$.

Zasadą jest, że obligacje i bony skarbowe, są nabywane i zbywane na przetargach. W kontekście omawianego w niniejszej pracy zagadnienia, symptomatyczne jest jednak to, że Ministrowi Finansów pozostawiono możliwość zawierania umów z podmiotami będącymi osobami fizycznymi, prawnymi oraz spółkami nieposiadającymi osobowości prawnej przyznających prawo zakupu lub przedstawiania do odkupu wskazanych papierów wartościowych poza przetargiem ${ }^{21}$. Uprawnienie to związane jest z urzeczywistnieniem przez Ministra celu, jakim jest zarządzanie długiem Skarbu Państwa. Jednocześnie Minister Finansów jest zobligowany do realizacji zasady jawności poprzez podawanie do publicznej wiadomości informacji o zawartych umowach. Zwrócić uwagę należy, że przepisy nie precyzują szczegó-

\footnotetext{
${ }^{16} \S 5$ rozporządzenia MF w sprawie warunków emitowania obligacji skarbowych oferowanych na rynkach zagranicznych.

${ }^{17}$ Realizację takiej funkcji dopuszcza także art. 49 ustawy z dnia 29 sierpnia 1997 r. o Narodowym Banku Polskim, Dz. U. z 2019, poz.1810 z późn. zm.

${ }^{18} \S 8$ rozporządzenia MF w sprawie warunków emitowania obligacji skarbowych oferowanych w sprzedaży hurtowej; § 8 rozporządzenia MF w sprawie warunków emitowania bonów skarbowych.

${ }^{19}$ Zob. np. Regulamin pełnienia funkcji Dealera Skarbowych Papierów Wartościowych z dnia z dnia 29 kwietnia 2019 r. [w:] https://www.gov.pl/web/finanse/dealerzy-skarbowych-papierow-wartosciowych [dostęp: 25.10.2019].

${ }^{20} \S 8$ ust. 2 rozporządzenia MF w sprawie warunków emitowania obligacji skarbowych oferowanych w sprzedaży hurtowej; $\S 8$ ust. 2 rozporządzenia MF w sprawie warunków emitowania bonów skarbowych.

${ }^{21} \S 3$ rozporządzenia MF w sprawie warunków emitowania obligacji skarbowych oferowanych w sprzedaży hurtowej; § 3 rozporządzenia MF w sprawie warunków emitowania bonów skarbowych.
} 
łowych uwarunkowań takiego działania Ministra Finansów, można odczytać jako pozostawienie mu szerokiej płaszczyzny do działań dyskrecjonalnych.

Sumując, z powyższego wynika, że Minister Finansów na podstawie rozporządzeń wykonawczych posiada uprawnienia do zawierania umów z różnymi uczestnikami rynku skarbowych papierów wartościowych. Jego zadaniem jest także ich usytuowanie do pełnienia poszczególnych funkcji związanych z emisją, sprzedażą i obsługą poszczególnych papierów wartościowych. W kontekście oceny roli Ministra Finansów reprezentatywny jest fakt, że urzeczywistnienie jego mocy decyzyjnej następuje w drodze umów zawieranych z poszczególnymi uczestnikami rynku, w których następuje uszczegółowienie ich uprawnień i obowiązków, drugim dokumentem pozostającym także w gestii Ministra Finansów na podstawie, którego następuje konkretyzacja warunków emisji jest list emisyjny, o czym niżej. Dodać wypada, że Ministrowi pozostawiono także uprawnienia bliżej nieskonkretyzowane do działań poza przetargami, co jak sygnalizowano, świadczy o jego dyskrecjonalnej władzy.

Minister Finansów posiada także inne wyłączne uprawnienia szczegółowe. Jednym $z$ istotnych jest prawo do odwołania lub unieważnienia przetargu przed przyjęciem ofert bez podania przyczyny. Do innych uprawnień potwierdzających jego uprzywilejowaną pozycję zaliczyć należy możliwość ogłoszenia przetargu dodatkowego, oferowanie papierów wartościowych w przetargu uzupełniającym, prawo do redukcji ofert niekonkurencyjnych po terminie składania ofert. Ponadto Minister Finansów może zastrzec sobie prawo do wezwania posiadaczy wybranych serii obligacji o określonym terminie wykupu do bezwarunkowego przedstawienia ich do przedterminowego wykupu. $\mathrm{W}$ takim przypadku obligacje nie podlegają oprocentowaniu od następnego dnia po przedterminowym wykupie. Innym uprawnieniem jest możliwość przyznania przez Ministra Finansów posiadaczowi obligacji w liście emisyjnym prawa do bezwarunkowego wezwania emitenta do przedterminowego wykupu obligacji.

Szczególna rola Ministra Finansów uwidacznia się także w obowiązku sporządzania i publikacji listu emisyjnego. Można w tym zakresie zwrócić uwagę na dwa aspekty: materialny i formalny. Pierwszy z nich wiąże się z charakterem i treścią listu emisyjnego. Drugi natomiast związany jest ze skutkami publikacji listu emisyjnego. Przedmiotowo w treści listu emisyjnego ujmowane są elementy wymagane przez ustawę o finansach publicznych, konkretyzujące świadczenia wynikające ze skarbowego papieru wartościowego i sposób ich realizacji (art. 98 ust. 3 u.f.p.). Zwrócić należy jednak uwagę na to, że ustawowo określone elementy listu emisyjnego nie są wskazane enumeratywnie, skoro użyto w ustawie sformułowania „W szczególności”. Wnioskować więc można, że o ostatecznej treści listu emisyjnego decyduje Minister Finansów, z tym, że nie może ona stać 
w sprzeczności z przepisami aktów normatywnych. List emisyjny jest dokumentem oficjalnym zawierającym informacje dotyczące określonego papieru dłużnego. W doktrynie nie ma jednolitego stanowiska co do charakteru prawnego listu emisyjnego. Porównywany jest on do prospektu emisyjnego, z tą różnicą, że jest niejako jego uproszczoną (skróconą) formą ${ }^{22}$. W nawiązaniu do tego porównania list emisyjny przez jednych Autorów uznawany jest jako dokument o charakterze informacyjnym ${ }^{23}$ skierowany do potencjalnych nabywców skarbowych papierów wartościowych, przez innych natomiast jako nośnik oświadczeń wiedzy oraz oświadczeń woli emitenta ${ }^{24}$. Nie ma wątpliwości jednak, że akt ten determinuje szczegółowe warunki emisji skarbowych papierów wartościowych dotyczące treści świadczeń wynikających ze skarbowego papieru wartościowego i sposób ich realizacji. Zatem skoro list emisyjny określa prawa i obowiązki stron stosunku zobowiązaniowego, wynikające z emisji i nabycia dłużnego papieru wartościowego, należy uznać, że jest jednym z kluczowych czynników całego procesu emisyjnego ze szczególnym uwzględnieniem określenia wiążących emitenta i adresata oferty nabycia skarbowych papierów wartościowych, elementów konstrukcyjnych stosunku zobowiązaniowego ${ }^{25}$. Sumując, można więc stwierdzić, że przedmiotowo list emisyjny definiuje elementy wpływające na relacje między potencjalnym nabywcą i emitentem papierów wartościowych, czyli Ministrem Finansów ${ }^{26}$. Podmiotowe ustosunkowanie się do zagadnienia listu emisyjnego uwidacznia rolę Ministra Finansów jako podmiotu uprawnionego do wydania listu emisyjnego. Ustawa o finansach publicznych przyznaje Ministrowi Finansów możliwość upoważnienia innego podmiotu do wydania listu emisyjnego dotyczącego skarbowych

${ }^{22}$ Tak: C. KosikowsKi, Nowa ustawa o finansach publicznych. Komentarz, Warszawa: Wydawnictwo LexisNexis 2010, s. 259; Z. Ofiarski, Komentarz do art. 98, [w:] M. KarlikowsKa, W. Miemiec, Z. Ofiarski [i in.], Ustawa o finansach publicznych. Komentarz, Wrocław: Wydawnictwo Presscom Sp. z o.o. 2010, s. 273.

${ }^{23}$ Dodać należy, że przypisanie prospektowi emisyjnemu funkcji informacyjnej wiąże się $\mathrm{z}$ dopuszczeniem przez ustawodawcę możliwości wprowadzania zmian jego treści w czasie jego ważności. C. Kosikowski, wskazuje, że je jest to istotna różnica pomiędzy prospektem emisyjnym a listem emisyjnym, zob. Kosikowski, Nowa ustawa, s. 259.

${ }^{24}$ Zob. m.in. A. CHLOPECKI, Glosa do postanowienia SN z 8 września 1995 r. sygn. akt III CZP 102/95, „Przegląd Ustawodawstwa Gospodarczego” 1 (1998), nr 1, s. 15 n. Na ten aspekt zwraca uwagę P. Zawadzka, wskazując, że w zakresie listu emisyjnego chodzi o sferę dominium (znamiona cywilnoprawne), a nie imperium (publicznoprawne), co znajduje odzwierciedlenie w dopuszczalnej drodze sądowej wynikającej z tego stosunku. List emisyjny jest aktem, który - jak wskazano w literaturze przedmiotu - nie może być aktem normatywnym kreującym prawa i obowiązki skuteczne erga omnes, a jest raczej cywilistycznym zapisem zobowiązań emitenta wobec przyszłych wierzycieli, wobec których jest składane oświadczenie (inter partes). Zob. ZawadZKa, Komentarz do art. 97, s. 638.

${ }^{25}$ Tak Mikos-Sitek, ZapadKa, Komentarz do art. 97, s. 399.

${ }^{26}$ Zob. OfIARSKI, Komentarz do art. 98, s. 274 oraz cytowana tam literatura. 
papierów wartościowych przeznaczonych na rynki finansowe. Wskazana norma kompetencyjna Ministra Finansów nie jest w żaden sposób doprecyzowana, ani co do ewentualnych cech podmiotu upoważnianego, ani sytuacji w jakiej takie realne upoważnienie mogłoby mieć miejsce. Można zatem przyjąć, że omawiana kompetencja jest przejawem dyskrecjonalności Ministra Finansów. Wydaje się, że pozostawienie Ministrowi Finansów dużej dowolności, a wręcz swobody w wyborze, powinno być ograniczone poprzez wykazanie związku między upoważnionym przez Ministra podmiotem emitującym list emisyjny z gospodarką finansową państwa. Minister Finansów jako organ reprezentujący Skarb Państwa ponosi odpowiedzialność za informacje zawarte w liście emisyjnym ${ }^{27}$.

Odrębnego zaznaczenia wymaga strona formalna listu emisyjnego. Należy rozważyć w tym kontekście kilka kwestii. Po pierwsze, należy podkreślić, że na Ministrze Finansów ciąży obowiązek podania do publicznej wiadomości szczegółowych warunków danej emisji. Ustawa o finansach publicznych nie wskazuje środków służących realizacji tego obowiązku. Nie zawarto także żadnego odesłania do obowiązującego ustawodawstwa. W tej sytuacji ustawowy zwrot ,podaje do publicznej wiadomości" ma charakter nieostry i wskazuje na pozostawienie Ministrowi pewnej elastyczności działania. Oczywiście odwoływanie się do innych aktów normatywnych odnoszących się do oferty publicznej może być pomocne ${ }^{28}$, wydaje się jednak, że nie jest to konieczne skoro Minister Finansów w wydanych przez siebie rozporządzeniach wykonawczych doprecyzował sposób publikacji listów emisyjnych i komunikatów. Jako sposób podania do publicznej wiadomości wskazał opublikowanie na stronie internetowej Ministerstwa Finansów lub w innych środkach masowego przekazu o zasięgu ogólnopolskim ${ }^{29}$, a także elektronicznych systemach informacyjnych ${ }^{30}$. Wybór sposobu publikacji przez Ministra Finansów

${ }^{27}$ Zob. L. LiPIEC-WARZECHA, Ustawa o finansach publicznych. Komentarz [on-line], Warszawa: Wydawnictwo ABC 2011, [w:] https://sip.lex.pl/\#/commentary/587300130/975702019-09-30 [dostęp: 9.11.2019]. Autorka ta wskazuje, że w sytuacji przeprowadzenia emisji skarbowych papierów wartościowych w sposób odmienny od określonego w liście emisyjnym lub naruszenia warunków emisji przy realizacji zobowiązań wynikających z papierów, skutkuje odpowiedzialnością odszkodowawczą Skarbu Państwa, reprezentowanego przez Ministra Finansów wobec inwestora. Odpowiedzialność ponosi również wtedy, gdy realizacja obowiązków następuje za pośrednictwem agenta emisji.

${ }^{28}$ Doktryna podejmując próbę zapełnienia tej luki odwołuje się do przepisów ustawy z dnia 29 lipca 2005 r. o ofercie publicznej i warunkach wprowadzania instrumentów finansowych do zorganizowanego systemu obrotu oraz o spółkach publicznych, Dz. U z 2019, poz. 623.

${ }^{29}$ Zob. § 7 rozporządzenia MF w sprawie warunków emitowania obligacji skarbowych oferowanych w sprzedaży hurtowej; $§ 7$ rozporządzenia MF w sprawie warunków emitowania bonów skarbowych.

${ }^{30} \S 8$ rozporządzenia MF w sprawie warunków emitowania obligacji skarbowych przeznaczonych na zamianę zobowiązań Skarbu Państwa; § 2 ust. 6 rozporządzenia MF w sprawie warunków emitowania obligacji skarbowych oferowanych w sieci sprzedaży detalicznej; § 11 rozporządzenia 
ma znaczenie praktyczne, gdyż przyjęta formuła pozwala na szybkie reagowanie na procesy zachodzące na rynku finansowym. Uznać więc należy, że ta swoista elastyczność pozostawiona Ministrowi jest uzasadniona pragmatyzmem.

Po drugie, bardzo istotnym aspektem godnym odnotowania jest uwarunkowanie dojścia emisji do skutku od podania do publicznej wiadomości listu emisyjnego. Można więc stwierdzić, że skuteczność emisji uzależniona jest realizacją przez Ministra Finansów zasady jawności. Zaznaczyć wypada, że chodzi tu o powszechne udostępnienie, a nie tylko informacje skierowane do potencjalnych inwestorów. Ustawa o finansach publicznych przypisała więc, czynności technicznej (formalnej) bardzo istotne znaczenie, dzięki realizacji której emisja dochodzi do skutku. Wydaje się również, że podanie do publicznej wiadomości listu emisyjnego, wiąże Ministra Finansów co do jego treści.

$\mathrm{Z}$ problematyką emisji skarbowych papierów wartościowych in ipsum wiąże się także upoważnienie Ministra Finansów do przeprowadzania operacji finansowych związanych z zarządzaniem długiem. Ustawa o finansach publicznych nie zawiera katalogu tych operacji, co pozostawia Ministrowi swobodę w ich doborze i stosowaniu pod warunkiem, że służą podstawowemu celowi, czyli sfinansowaniu potrzeb pożyczkowych budżetu państwa, a także mają związek z zarządzaniem długiem Skarbu Państwa. Oprócz wyżej wskazanych uwag odnoszących się do szeregu kompetencji Ministra Finansów w zakresie emisji papierów wartościowych służącej sfinansowaniu pożyczkowych potrzeb budżetu państwa, można także wyszczególnić w tym aspekcie element, którym jest uzasadnianie zarządzaniem długiem Skarbu Państwa. Ustawa o finansach publicznych dopuszcza możliwość wyemitowania przez Ministra Finansów skarbowych papierów wartościowych w kwocie wyższej od wartości nominalnej zbytych papierów wartościowych (art. 102 ust. 3 u.f.p.), z wyraźnym zastrzeżeniem, że działanie to podejmowane jest „w celach związanych z zarządzaniem długiem Skarbu Państwa”. Na etapie prac legislacyjnych uzasadniono wprowadzenie tego rozwiązania koniecznością „zapewnienia płynności rozliczeń w ramach systemu konsolidacji”. Wyemitowane przez Ministra Finansów papiery wartościowe w kwocie wyższej aniżeli wynikałoby to z przetargu w założeniu projektodawców mają służyć zabezpieczeniu transakcji dokonywanych przez Ministra w ramach zarządzania długiem Skarbu Państwa $^{31}$. Argumentacja uzasadniająca przyznanie Ministrowi Finansów omawianej kompetencji, podniesiona na etapie prac parlamentarnych, była raczej zdawkowa,

MF w sprawie warunków emitowania obligacji skarbowych uprawniających do określonych świadczeń niepieniężnych.

${ }^{31}$ Zob. Sprawozdanie z posiedzenia Sejmowej Komisji Finansów Publicznych z dnia 30 listopada 2010 r., dotyczącego rządowego projektu ustawy o zmianie u.f.p. oraz niektórych innych ustaw, Druk Sejmowy nr 3576, Sejm VI kadencji. 
podobnie jak i przemilczany zarzut o zbyt daleko idącej delegacji dla Ministra Finansów ${ }^{32}$. Wydaje się, że brak wskazania, w jakich sytuacjach omawiane działania Minister może podjąć, na rzecz bardzo ogólnego i pojemnego treściowo „celów związanych z zarządzaniem długiem Skarbu Państwa", w praktyce prowadzić może do podejmowania tych działań w sytuacjach, jakie Minister Finansów uzna za właściwe z punktu widzenia zarządzania długiem Skarbu Państwa. Świadczy to o bardzo dużej elastyczności przepisów będących podstawą prawną działania Ministra Finansów ${ }^{33}$.

Minister Finansów w imieniu Skarbu Państwa jest upoważniony do nabywania skarbowych papierów wartościowych w celu zarządzania długiem Skarbu Państwa (art. 79 ust. 2 u.f.p.). W takiej sytuacji skarbowe papiery wartościowe nie podlegają umorzeniu ${ }^{34}$. Ze wskazanej kompetencji wynika kilka wniosków. Pierwszą kwestią jest użycie w celu określenia kompetencji Ministra Finansów w akcie normatywnym zwrotu „nabywane”. W doktrynie termin ten jest jednoznacznie rozumiany jako pojęcie szersze niż „wykup”, gdyż odnosi się do różnych czynności prawnych podejmowanych przez Ministra Finansów. Są nimi zarówno przedterminowy wykup, odkup, przedterminowa konwersja długu, zamiana, refinansowanie ${ }^{35}$. Można zatem stwierdzić, że Minister Finansów dysponuje szerokim wachlarzem możliwości podejmowanych czynności prawnych ${ }^{36}$. Drugą kwestią jest znaczenie czynności nabywania przez Skarb Państwa skarbowych papierów wartościowych.

32 Tamże.

${ }^{33}$ Wydaje się w tym kontekście szczególnego znaczenia nabiera określenie celów związanych z zarządzaniem długiem Skarbu Państwa w Strategii zarządzania długiem sektora finansów publicznych. Wspomnieć należy, że zasadniczym celem powtarzanym w strategiach opracowywanych w kolejnych latach jest minimalizacja kosztów obsługi długu w długim horyzoncie czasu. Cel ten jest rozumiany w dwóch aspektach: doboru instrumentów oraz zwiększania efektywności rynku skarbowych papierów wartościowych. Zob. np. Strategia zarządzania długiem sektora finansów publicznych na lata 2016-2019, s. 5 [w:] http://orka.sejm.gov.pl/Druki7ka.nsf/0/DA631E9FA03F334 1C1257ED70031C79E/\%24File/3988-strategia.pdf [dostęp: 30.10.2019], s. 5.

${ }^{34}$ Zwrócić uwagę należy dopuszczalność umarzania papierów wartościowych przewiduje art. $921^{14}$ k.c. jednocześnie odsyłając do przepisów szczególnych. W ustawie o finansach publicznych, którą także należy traktować jako przepisy szczególne w rozumieniu k.c., umorzenie papierów wartościowych jest związane z ich wykupem, czyli spełnieniem świadczenia wynikającego z papieru wartościowego (zob. art. 79 ust. 1 u.f.p.).

${ }^{35}$ Z. Ofiarski, Komentarz do art. 79, [w:] Karlikowska, Miemiec, Ofiarski [i in.], Ustawa o finansach publicznych. Komentarz, s. 228.

${ }^{36}$ Szczegółowo możliwości podejmowania różnych czynności prawnych wypełniających zakres pojęciowy użytego w przepisach ustawy terminu „,nabywanie” wynika z omówionych wyżej rozporządzeń wykonawczych określających warunki emisji poszczególnych papierów wartościowych. W tych rozporządzeniach Minister Finansów precyzuje uwarunkowania czynności prawnych, do których jest uprawniony. Podkreślić należy, że chodzi tu o czynności dokonywane przed upływem terminu realizacji zawartych $\mathrm{w}$ nich praw. 
W literaturze wskazuje się bowiem iż w tym przypadku następuje confusio, czyli skupienie w jednym podmiocie funkcji wierzyciela i dłużnika $\mathrm{z}$ tytułu skarbowych papierów wartościowych ${ }^{37}$. Co w sensie ścisłym skutkuje skrajną zmianą skutków prawnych owego nabywania papierów wartościowych. Nabywanie przez Skarb Państwa skarbowych papierów wartościowych w celu zarządzania długiem nie powoduje wygaśnięcia zobowiązania, a w związku z tym utraty ważności papieru wartościowego. Ratio legis tego instrumentu pozostającego w rękach Ministra Finansów są względy związane z obniżeniem ryzyka kursowego oraz redukcją kosztów obsługi długu, gdyż papiery te mogą być wprowadzane do obrotu na rynku wtórnym $^{38}$. Trzecia kwestia dotyczy możliwości dokonywania dalszych ,innych operacji finansowych" w tym pożyczki, na nabytych w powyższy sposób skarbowych papierach wartościowych (art. 78 h u.f.p.). Podmiotem upoważnionym do dokonywania tych czynności jest Minister Finansów. Po czwarte, podkreślić należy, że omówiona powyżej kategoria papierów skarbowych, która w wyniku realizacji celu zarządzania długiem Skarbu Państwa, na podstawie czynności prawnych dokonanych przez Ministra Finansów zyskała szczególny status i przeznaczenie podlega rejestracji na rachunku Ministra Finansów.

\section{PODSUMOWANIE}

W niniejszym artykule omówiono jedną z trzech płaszczyzn badawczych związanych z zaciąganiem zobowiązań w imieniu Skarbu Państwa, czyli problematyki emisji i wystawiania skarbowych papierów wartościowych. Przedstawiona analiza wskazuje, iż Minister Finansów odgrywa główną rolę w procesach związanych $\mathrm{z}$ emisją lub wystawianiem skarbowych papierów wartościowych. Jego uprawnienia nie doznają $\mathrm{w}$ zasadzie ograniczeń ze strony innych podmiotów. Zmiany strukturalne w Radzie Ministrów polegające na likwidacji teki Ministra Skarbu, spowodowały, że w omawianym obszarze prawno finansowym nie jest wymagany udział innych ministrów w realizacji kompetencji Ministra Finansów. Podobnie nie jest wymagane opiniowanie w omawianym zakresie przez Prokuratorię Generalną. Biorąc zaś pod uwagę proces przygotowania projektu ustawy budżetowej, trzeba przyznać, iż na ograniczenia wynikające z corocznych ustaw budżetowych odnoszące się do wysokości emisji, bezpośredni wpływ ma główny jej twórca, czyli Minister Finansów. Jest to zatem główny podmiot decyzyjny, niepodzielnie skupia-

${ }^{37}$ Zob. J. FrąTCZAK, Umarzanie skarbowych papierów wartościowych a zasada dematerializacji papierów wartościowych, „Przegląd Prawa Handlowego” 8 (2006), s. 45.

${ }^{38}$ Zob. PanfiL, Prawne i finansowe, s. 107, 300. 
jący działania prowadzące do zaciągania zobowiązań w imieniu Skarbu Państwa w obszarze emisji papierów wartościowych: począwszy od realizacji przyznanych mu uprawnień prawotwórczych, gdzie określa warunki emisji skarbowych papierów wartościowych, poprzez dokonywanie czynności planistycznych oraz w zakresie organizacji rynku skarbowych papierów wartościowych, aż po zawieranie umów z agentami emisji, Dealerami Skarbowych Papierów Wartościowych, a także innymi uczestnikami rynku skarbowych papierów wartościowych. W niniejszym artykule wykazano, że szczególna pozycja Ministra Finansów wynika nie tylko z szerokiego zakresu jego kompetencji, ale także ze sformułowania przepisów prawa finansów publicznych, pozostawiającego temu organowi szerokie pole do dyskrecjonalnych działań nieograniczonych formalnie kompetencjami realizowanymi przez inne organy. Szczegółowe wnioski de lege lata i de lege ferenda zostaną zaprezentowane w kolejnej części artykułu.

\section{BIBLIOGRAFIA}

\section{ŹRÓDEA PRAWA}

Konstytucja Rzeczypospolitej Polskiej z dnia 2 kwietnia 1997 r., Dz. U. Nr 78, poz. 483 z późn. zm. Ustawa z dnia 23 kwietnia 1964 r. Kodeks cywilny, Dz. U. z 2019 r., poz. 1145 z późn. zm.

Ustawa z dnia 8 maja 1997 r. . o poręczeniach i gwarancjach udzielanych przez Skarb Państwa oraz niektóre osoby prawne, Dz. U. z 2020 r., poz. 122.

Ustawa z dnia 29 sierpnia 1997 r. o Narodowym Banku Polskim, Dz. U. z 2019, poz.1810 z późn. zm. Ustawa z dnia 29 lipca 2005 r. o ofercie publicznej i warunkach wprowadzania instrumentów finansowych do zorganizowanego systemu obrotu oraz o spółkach publicznych, Dz. U z 2019, poz. 623. Ustawa z dnia 27 sierpnia 2009 r. o finansach publicznych, Dz. U. z 2019 r., poz. 869 z późn. zm. Ustawa budżetowa na 2019 rok, Dz. U. z 2019 r., poz. 198.

Ustawa budżetowa na rok 2020 z dnia 14 lutego 2020 r., Dz. U. poz. 571.

Rozporządzenie Ministra Finansów z dnia 3 grudnia 2010 r. w sprawie warunków emitowania obligacji skarbowych oferowanych w sieci sprzedaży detalicznej, Dz. U. z 2019 r., poz. 944.

Rozporządzenie Ministra Finansów z dnia 3 grudnia 2010 r. w sprawie warunków emitowania obligacji skarbowych przeznaczonych na zamianę zobowiązań Skarbu Państwa, Dz. U. Nr 237, poz. 1574.

Rozporządzenie Ministra Finansów z dnia 15 grudnia 2010 r. w sprawie warunków emitowania obligacji skarbowych oferowanych na rynkach zagranicznych, Dz. U. z 2016 r., poz. 1884.

Rozporządzenie Ministra Finansów z dnia 28 grudnia 2010 r. w sprawie warunków emitowania obligacji skarbowych uprawniających do określonych świadczeń niepieniężnych, Dz. U. Nr 258, poz. 1756 .

Rozporządzenie Ministra Finansów z dnia 30 sierpnia 2013 r. w sprawie warunków emitowania bonów skarbowych, Dz. U. poz. 1088 z późn. zm.

Rozporządzenie Ministra Finansów z dnia 30 sierpnia 2013 r. w sprawie warunków emitowania obligacji skarbowych oferowanych w sprzedaży hurtowej, Dz. U poz. 1089 z późn. zm. 


\section{LITERATURA}

CHŁOPECKI Aleksander: Glosa do postanowienia SN z 8 września 1995 r. sygn. akt III CZP 102/95, Przeglad Ustawodawstwa Gospodarczego 1 (1998), s. 15-22.

FrątCZaK JoannaL Istota skarbowych papierów wartościowych, Przegląd Prawa Handlowego 8 (2005), s. 43-46.

FRĄTCZAK Joanna: Umarzanie skarbowych papierów wartościowych a zasada dematerializacji papierów wartościowych, Przegląd Prawa Handlowego 8 (2006), s. 44-47.

JAŁOSZYŃSKA Katarzyna: Z problematyki prawnej skarbowych papierów wartościowych, [w:] Prawo finansowe i nauka prawa finansowego na przełomie wieków, red. A. Kostecki, Kraków: Wydawnictwo Zakamycze 2000.

Kosikowski Cezary: Nowa ustawa o finansach publicznych. Komentarz, Warszawa: Wydawnictwo LexisNexis 2010.

KuCiA-GuŚCiora Beata: Kontrola i programowanie państwowego długu publicznego z perspektywy kompetencji ministra właściwego do spraw finansów publicznych, Krytyka Prawa. Niezależne Studia nad Prawem 1 (2017), s. 63-86.

KuCiA-Guściora Beata: Rola ministra właściwego do spraw finansów publicznych w kształtowaniu zakresu państwowego długu publicznego. Wybrane problemy, Roczniki Nauk Prawnych 27 (2017), nr 4, s. 41-62.

LiPIEC-Warzecha Ludmiła: Ustawa o finansach publicznych. Komentarz [on-line], Warszawa: Wydawnictwo ABC 2011, [w:] https://sip.lex.pl/\#/commentary/587300130/975702019-09-30 [dostęp: 9.11.2019].

Mikos-Sitek Agnieszka, ZaPAdKa Piotr: Komentarz do art. 97, [w:] Ustawa o finansach publicznych. Komentarz, red. W. Misiąg, Warszawa: C.H. Beck 2019, s. 397-400.

Nizioł Krystyna: Państwowy dług publiczny - aspekty normatywne, Szczecin: Polgres Multimedia 2013.

Ofiarski Zbigniew: Komentarz do art. 79, [w:] Maria Karlikowska, Wiesława Miemiec, Zbigniew OfiarsKi [i in.], Ustawa o finansach publicznych. Komentarz, Wrocław: Wydawnictwo Presscom Sp. z o.o. 2010, s. 228.

Ofiarski Zbigniew: Komentarz do art. 98, [w:] Maria Karlikowska, Wiesława Miemiec, Zbigniew OfiarsKi [i in.], Ustawa o finansach publicznych. Komentarz, Wrocław: Wydawnictwo Presscom Sp. z o.o. 2010, s. 272-274.

OfIARSKi Zbigniew: Komentarz do art. 3, [w:] Ustawa o finansach publicznych. Komentarz, red. Z. Ofiarski, Warszawa: Wolters Kluwer 2019, s. 87-89.

OfiARSKi Zbigniew: Aspekty prawne reglamentacji emisji skarbowych papierów wartościowych o charakterze dłużnym, [w:] Deficyt budżetowy i dług publiczny w wybranych krajach europejskich, red. E. Ruśkowski, Białystok: Wydawnictwo Wyższej Szkoły Finansów i Zarządzania w Białymstoku 2003, s. 227-240.

PANFil Przemysław: Prawne i finansowe uwarunkowania długu skarbu państwa, Warszawa: Wydawnictwo Wolters Kluwer 2011

ZawadzKa Patrycja: Komentarz do art. 97, [w:] Ustawa o finansach publicznych. Komentarz, red. Z. Ofiarski, Warszawa: Wolters Kluwer 2019, s. 635-639. 


\section{INNE MATERIALY}

Regulamin pełnienia funkcji Dealera Skarbowych Papierów Wartościowych z dnia z dnia 29 kwietnia 2019 r. [w:] https://www.gov.pl/web/finanse/dealerzy-skarbowych-papierow-wartosciowych [dostęp: 25.10.2019].

Sprawozdania z wykonania budżetu państwa w latach 2000-2018, [w:] https://www.gov.pl/web/ finanse/wykonanie-budzetu-panstwa [dostęp: 31.11.2019].

Sprawozdanie z posiedzenia Sejmowej Komisji Finansów Publicznych z dnia 30 listopada 2010 r., dotyczącego rządowego projektu ustawy o zmianie u.f.p. oraz niektórych innych ustaw, Druk Sejmowy nr 3576, Sejm VI kadencji.

Strategia zarządzania długiem sektora finansów publicznych na lata 2016-2019, [w:] http://orka sejm.gov.p1/Druki7ka.nsf/0/DA631E9FA03F3341C1257ED70031C79E/\%24File/3988-strategia. pdf [dostęp: 25.10.2019].

\section{ROLA MINISTRA FINANSÓW W ZACIĄGANIU ZOBOWIĄZAŃ FINANSOWYCH W IMIENIU SKARBU PAŃSTWA. CZĘŚĆ I}

\section{Streszczenie}

W artykule omówione zostało zagadnienie zaciągania zobowiązań w imieniu Skarbu Państwa realizowane poprzez przyznanie szczególnych kompetencji w tym zakresie Ministrowi Finansów. Dokonana analiza norm określających zasady zaciągania tychże zobowiązań wskazuje na szerokie kompetencje Ministra Finansów świadczące o jego szczególnym położeniu prawnym. Minister Finansów odgrywa główną rolę w procesach związanych z emisją lub wystawianiem skarbowych papierów wartościowych. Jest głównym podmiotem decyzyjnym, niepodzielnie skupiającym działania prowadzące do zaciągania zobowiązań w imieniu Skarbu Państwa w obszarze emisji papierów wartościowych: począwszy od realizacji przyznanych mu uprawnień prawotwórczych, gdzie określa warunki emisji skarbowych papierów wartościowych, poprzez dokonywanie czynności planistycznych oraz w zakresie organizacji rynku skarbowych papierów wartościowych, aż po zawieranie umów z agentami emisji, Dealerami Skarbowych Papierów Wartościowych, a także innymi uczestnikami rynku skarbowych papierów wartościowych. Szczególna pozycja Ministra Finansów wynika nie tylko z szerokiego zakresu jego kompetencji, ale także ze sformułowania przepisów prawa finansów publicznych, pozostawiającego temu organowi szerokie pole do dyskrecjonalnych działań nieograniczonych formalnie kompetencjami realizowanymi przez inne organy.

Słowa kluczowe: Minister Finansów; zobowiązania Skarbu Państwa; skarbowe papiery wartościowe

\section{THE ROLE OF THE MINISTER OF FINANCE IN INCURRING FINANCIAL OBLIGATIONS ON BEHALF OF THE TREASURY. PART I}

\section{Sum mary}

The article discusses the issue of incurring liabilities on behalf of the Treasury, implemented by granting special competences in this respect to the Minister of Finance. The analysis of standards defining the principles of assuming these obligations indicates the broad competences of the Minister of Finance confirming his special legal position. The Minister of Finance plays an important role in the processes related to the issue of Treasury securities. Is the main decision-making entity that 
integrates actions leading to incurring obligations on behalf of the Treasury in the field of issue of securities: starting from the implementation of the right to issue rights, if it determines the conditions of issue of treasury securities, through planning and organization of the Treasury securities market , to conclude agreements with issue agents, treasury securities dealers, as well as other participants of the treasury securities market. The special position of the Minister of Finance results not only from the wide range of his competences, but also from the formulation of public finance law, leaving this body a wide range of discretionary measures that are not formally limited by the competences implemented by other bodies.

Key words: Minister of Finance; treasury obligations; treasury securities 